\author{
Review Article
}

\title{
UTILITY OF VAJIKARANA IN GENERAL HEALTH- A REVIEW
}

\section{Anusree Dileep $^{1 *}$, Sreelekshmi.S², Vandana Rani.M3 ${ }^{3}$, Delvin.T.Robin ${ }^{4}$, Meera.S ${ }^{5}$}

${ }^{*}$ Associate Professor, ${ }^{2}$ PG Scholar, ${ }^{3}$ Professor and Head of the Department, ${ }^{4}$ Associate Professor, ${ }^{5}$ Assistant Professor, Department of Swasthavritta, (Social and Preventive Medicine), Amrita School of Ayurveda, Amritapuri, Amrita Vishwa Vidyapeetham, India.

\begin{tabular}{l} 
Article info \\
\hline Article History: \\
Received: 02-08-2021 \\
Revised : 14-08-2021 \\
Accepted: 28-08-2021 \\
Published: 18-09-2021 \\
\hline KEYWORDS: \\
Vajikarana, \\
Ayurveda, \\
aphrodisiacs, neuro- \\
endocrine immune \\
system, Vrishya \\
chiktsa, Ojas and sex \\
hormones.
\end{tabular}
hormones.

\begin{abstract}
Objective: Vajikarana or Vrishya chikitsa is the branch of Ayurveda dealing with reproductive health and virility. Though this branch makes use of drugs under the category of aphrodisiac, the multifaceted effect of those is under explored. The properties of disease prevention and restoration might be the attribute benefited in sexual health too. This paper intends to explore the general health benefits of Vajikarana drugs.

Data source: The data related to the aphrodisiac drugs are located in classical texts of Ayurveda and online journals with keywords "Vajikarana, Ayurveda, aphrodisiacs, neuroendocrine immune system, Vrishya chiktsa, Ojas and sex hormones". The relevant scripts were selected and appropriate data from 8 articles and 18 chapters were extracted for the final manuscript construction.

Results: The drugs like Ashwangadha, Satavari, Atmagupta, Sweta musali and Masha proved to have neuro-endocrinological effects, psycho-neuro-immunological effects, antiinflammatory and anti-oxidant properties apart from aphrodisiac effects. It stabilizes Tridosha, Saptadathu and eventually Ojas, and calms mental faculties.

Conclusion: The proper use of the Vajikarana formulations imparts qualities like good physique, potency, strength and complexion. The benefits of Vajikarana can be incorporated into other health conditions also. The practice of Vajikarana corrects the deformities of reproductive systems and in turn balances other body functions. Advanced research on the health benefits and enhancing sexual potency of women should be carried out on Vajikarana therapy. This will aid prevention of diseases which is a major health standpoint in the current day scenario.
\end{abstract}

\section{INTRODUCTION}

Ayurveda has classified facets of its treatment into eight major branches. Vajikarana is one of these eight limbs of Ayurveda. Though enumerated last, it has prime importance in maintaining and enriching the virility of a man. The whole branch, also known as Vrishya chikitsa, concentrates on improving the sexual potency by medications, especially aphrodisiac drugs that can improve the quality of semen and improve the health of progeny.

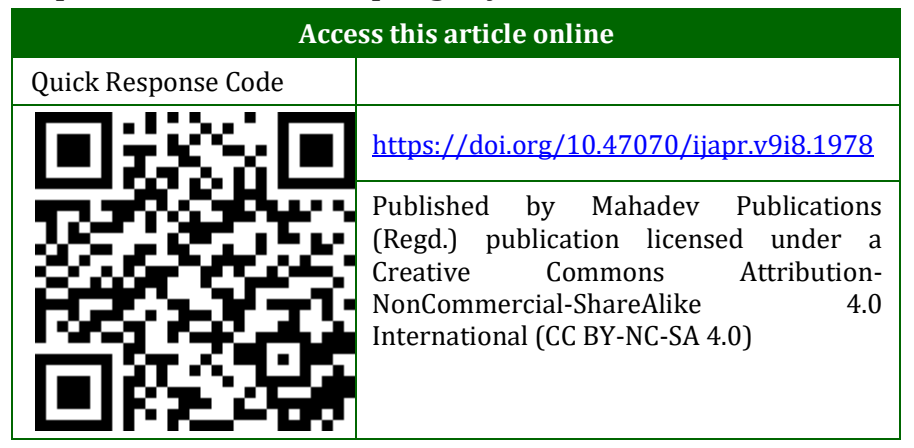

The benefits of Vajikarana therapy are multifaceted. Treatment of common sexual disorders and promotion of sexual health are the common benefits of Vajikarana therapy. In addition to the above, the practice of Vajikarana therapy will also benefit disease prevention and health promotion in normal healthy individuals. A person's health is the state of their body and the point to which it is free from illness. The concept of the practice of Vajikarana for general wellbeing is not seen much in practice and it needs further research and more scientific explanation. The utility of Vajikarana drugs in general health need to be explored.

\section{Methodology}

Classical text books of Ayurveda such as Ashtanga Hridaya, Charaka Samhita, Susrutha Samhita, Ashtanga Samgraha, Kashyapa Samhita and Bhavaprakasha was reviewed to analyze the concept of Vajikarana. Databases such as PubMed, Google Scholar, 
Science direct etc. were searched using the keywords like Vajikarana, Ayurveda, aphrodisiacs, neuro- endocrine immune system, Vrishya chiktsa, Ojas and sex hormones.

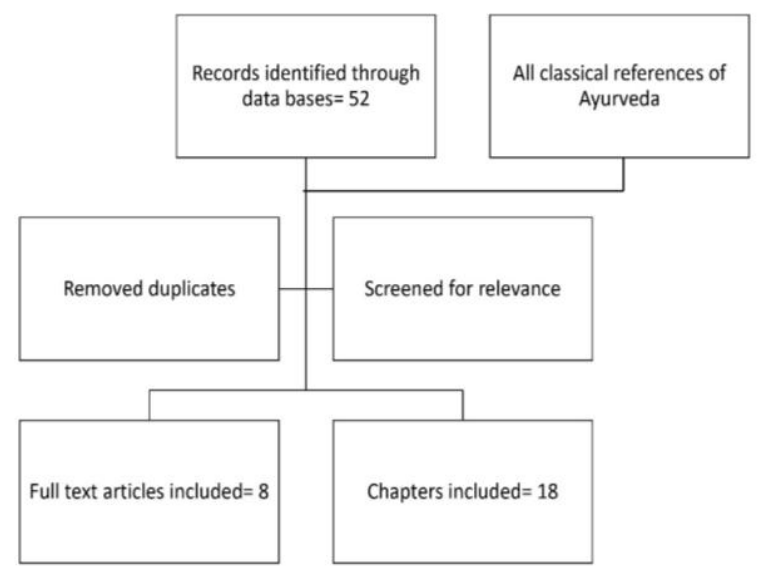

Figure 1: Methodology

\section{Vajikarana in Ayurveda, its importance and application}

The word Vajikarana is an agglomeration of two words, Vaji and Karana. The meaning of Vaji is horse, usually used as a symbol of sexual potency and Karana denotes power. The practice of Vajikarana formulations makes a person endowed with good physique, potency, strength, complexion and sexually strong as that of an eight year old horse.[1]

According to Ayurveda, the treatment or medicine which makes the man capable of strength as that of a horse (a symbol for sexual potency), and which imparts nourishment to the body is known as Vajikarana. It acts as the greatest promoter of strength and vigour.[2] The therapy as a whole imparts contentment, nourishment, continuity of progeny and boundless happiness. Sexuality and reproduction which are the two major components for a healthy life of an individual get enhanced. A man having numerous progenies is like one who has plentiful forms of actions and knowledge. In addition to the benefits on the reproductive system, individual quality and longevity of life increase.[3] Simultaneously physical and physiological health of the individual is also improved. ${ }^{[4]}$ Along with these, Vajikarana therapy rectifies the condition of erectile dysfunction by increasing the period of erections, preventing premature ejaculations, enabling to produce healthy offspring, providing stimulation for sexual activity, reducing tiredness after cohabitation, bringing prosperity, strength and auspiciousness to individuals, and imparting willpower, memory and intellect to the individual.[5]

\section{General health- Basic Concepts in Ayurveda}

Ayurveda explains the concept of health as the equilibrium of Dosha, Dhathu, Mala and the balance of self, sense organs and mind. This is similar to that which is derived by the World Health Organization as a state of complete physical, mental and social well- being and not merely the absence of disease or infirmity. The concept of general health can thus be easily explained by detailing the basic concepts of these components which stabilize the wellbeing.

\section{Tridosha ${ }^{[6]}$}

- The concept of Tridosha is related to physiological regulation through the unified functioning of the Doshas namely Vata, Pita and Kapha. Essentially Dosha plays a vital role in maintaining health and manifestation of diseases. The fundamental goal behind Ayurveda treatment modality is to create or to generate the harmonious state of the above three components.

\section{Saptadhatu}

Food materials which are composed of Pancha mahabhuta (five basic elements) on digestion divide into two forms, Ahara prasada bhaga and Kittabhaga, Ahara prasada bhaga or the substantial part transforms into Saptadhatu (seven constructive tissues of the body). These seven elements are essential for the growth and sustainability of the body. The formation of Dhatu takes place in a sequential manner. The first element Rasa transforms into Raktha, Rakta to Mamsa, Mamsa to Medas, Medas to Asthi, Asthi to Majja, Majja to Sukla.[7]

\section{Ojas}

The end product of a proper sequential metabolism of seven Dathu is Ojas. The Kapha dosha at its normal state is also expressed as Ojas. It is correlated to the inherent immunity of the body and is the first component appearing in intrauterine life. This element which is superior among all sites of vitality imparts strength to the body and mind. ${ }^{[8,9,10,11]}$

The drugs used for Vajikarana, by its virtue, stabilizes these basic components of well-being and promote health. 


\section{Classical Reference and Mode of Administration}

All classical textbooks of Ayurveda detail Vajikaran and its effectiveness in sexual health. It follows a particular pattern of administration for enhanced efficacy.

The drugs used for Vajikarana possess the attributes of Madhura (sweet), Snigdha (unctuous), Jeevaniya (invigorating), Brimhana (bulk forming), Guru (heavy to digest) and one which causes Harsha (excitement).[12] The individual aged between 20 and 70 years and those who are suffering from impotence, those who indulge in recurrent sexual activity or those who have a diminished production of Shukra (semen) shall undergo this therapy. Individuals below or beyond the age limit, Person who lack control over their sense organs, and those who have impotency of hereditary or traumatic origin are forbidden in undergoing these procedures.[13]

Before the administration of Vajikarana ${ }^{[14]}$, the individual should undergo certain preoperative procedures such as Sodhana (purification) to attain maximum benefits from the therapy. When the body channels are occupied with the toxic element called $A m a$, the medicine will not work properly. So, the person planning to undergo Vajikarana chikitsa should be subjected to Sneha, Sweda, Asthapana and Anuvasana Vasti. After purifying the body, Vajikarana recipes are enriched with milk, meat soup, boiled rice along with ghee, sugar and honey.[15] This will improve the overall health and quality of Shukra dhathu.

Certain food and regimen should be practiced and few should be avoided during the therapy. Emotional imbalance should be restricted and the person should refrain from excessively using sour, salty and pungent food, and incompatible food.

\section{Formulations [16.17,18]}

There is one chapter each for Vajikarana in Susrutha Samhitha and Ashtanga Hridaya while Acharya Charaka has one elaborated version dedicating four chapters for Vajikarana.

\section{Table 1: Summary of Charaka Samhitha}

\begin{tabular}{|l|l|l|}
\hline S.no & Name of the chapter & $\begin{array}{l}\text { Number of } \\
\text { formulations }\end{array}$ \\
\hline 1 & Samyogasaramuleeyam & 15 \\
\hline 2 & Asikthaksheereeyam & 8 \\
\hline 3 & Mashaparniprabhruteeyam & 15 \\
\hline 4 & Pumanjatabaladhikam & 12 \\
\hline
\end{tabular}

Table 2: Formulations from Ashtanga Hridaya

\begin{tabular}{|l|l|l|}
\hline S.no & $\begin{array}{l}\text { Name of } \\
\text { chapter }\end{array}$ & Number of formulations \\
\hline 1 & Vajikaranam & 13 \\
\hline
\end{tabular}

Table 3: Formulations from Susrutha Samhita

\begin{tabular}{|l|l|l|}
\hline S.no & Name of chapter & Number of formulations \\
\hline 1 & $\begin{array}{l}\text { Ksinabaliyam } \\
\text { vajikarana } \\
\text { chikitsitam }\end{array}$ & 15 \\
\hline
\end{tabular}

General health benefits of selected Vajikarana drugs

Vajikarana is a distinctive category of Rasayana (rejuvenate therapy), having anti-stress and adaptogenic properties. Vajikarana drugs act inside the body by regulating the neuro-endocrine- immune system. ${ }^{[19]}$ It was noted that most of the Vajikarana drugs have a general health promoting profile apart from their action in enhancing sexual potency. Thus, the use of these can be adopted for general well-being.

\section{Ashwagandha (Withania Somnifera)}

Ashwagandha (Withania Somnifera) is a widely used herb as a nervine tonic. The root of Ashwagandha possesses the qualities like aphrodisiac, diuretic, tonic and stimulant properties. Ashwagandha is a powerful adaptogen and upturns the body's suppleness towards stress. The body's defense mechanism against diseases is improved by refining cell mediated immunity.[20]

\section{Atmagupta (Mucuna Pruriens)}

Atmagupta (Mucuna pruriens) is a well-known medicinal plant that is mainly used for the treatment of parkinsonism. Active ingredient present in the plant is L-dopa which is responsible for the therapeutic benefits.[21] $M$. puriens showed a great anti-oxidant potential and free radical scavenging activity.[22]

\section{Shweta Musli (Chlorophytum Borivilianum)}

Shweta Musli (Chlorophytum borivilianum) possesses anti-inflammatory and anti-oxidant activity.[23]

\section{Masha (Vigna Mungo)}

Masha (Vigna Mungo) is a traditional medicinal plant used for the treatment of a variety of conditions. The immuno stimulatory effect of Masha was evaluated using an animal model. Induction of immunostimulatory effect was analyzed by parameters such as Sheep Red Blood Cells (SRBC) induced humoral antibody titer, SRBC induced delayed-type hypersensitivity, neutrophil adhesion and in vivo phagocytosis after host treatment with the extract. The results here indicated that primary and secondary antibody titers in the rats were significantly increased by treatment with the V. mungo extract as compared with those noted among rats in a control group. The apparent immunostimulatory effect of the V. mungo seed extract might be attributed to an augmentation of humoral and cell-mediated responses, phagocytosis, and hematopoiesis in the treated rats. The findings in this study suggest that V. mungo seed extract possesses profound immunostimulatory activities.[24] 
Int. J. Ayur. Pharma Research, 2021;9(8):57-63

Apart from these formulations, which are mentioned

for improving sexual the potency of males, single drugs

are mentioned

in Kashyapa Samhita

for

Table 4: drugs for female reproductive health

\begin{tabular}{|c|l|l|l|}
\hline S.no & Name of drug & Properties & Indications \\
\hline 1 & Satavari & $\begin{array}{l}\text { Seetaveerya, Snigdha, Kashaya, Madhurarasa, Vrishya, } \\
\text { Rasayana }\end{array}$ & $\begin{array}{l}\text { Vandhyatwam } \\
\text { Frigid women }\end{array}$ \\
\hline 2 & Satapushpa & Madhura rasa, Brimhana, Balyam, Rithu pravarthini & $\begin{array}{l}\text { Vandhaya } \\
\text { Shanda }\end{array}$ \\
\hline 3 & Lashuna & $\begin{array}{l}\text { Katurasa (seed), Lavana, Tikta (stem), Kashaya } \\
\text { (leaves), Madhura Vipaka, Brimhana }\end{array}$ & Vandhyatwa \\
\hline
\end{tabular}

- Satapushpa (Anethum Sowa): Enhances female health by acting on the reproductive system. Phytoestrogens present in the drug effectively prevent menopausal complications such as hot flush, vaginitis, anxiety and osteoporosis.[26]

- Satavari (Asparagus Racemosus): The drug regulates the serum calcium level and exerts a beneficial effect in preventing osteoporosis.[27]

- Lashuna (Allium sattivum): It possesses antioxidant property and Allicin present in the drug increases blood supply to the reproductive system.[28]

\section{DISCUSSION}

\section{Utility of Vajikarana in Health}

The benefits of Vajikarana can be utilized in many conditions. A better comprehension of the basic concepts of Ayurveda like the concept of Tridosha, Saptadhatu and Ojas will be necessary before initiating a discussion on the health aspects of Vajikarana.

When coitus is performed daily without taking Vajikarana dravyas, it leads to vitiation of Tridosha and progressive pathological changes like loss of compactness of muscles, looseness of joints, vitiation of Rakta (blood tissue), excessive production of Meda (fatty tissue), failure of production of Sukra (reproductive tissues) and deprivation of Ojas (Vital factor).[29] This process leads to the formation of akalaja jara (untimely aging). Aging which occurs untimely can be prevented by following the rules of Swasthavritta (preventive and social medicine). Dinacharya (daily regimen), Ratricharya (night regimen) and Ritucharya (seasonal regimen) must be complied with to maintain health.[${ }^{[30]}$ By the application of Vajikarana therapy, untimely ageing as well as general health can be maintained. Ojas is known as the essence of Saptadhatu (body tissues) susceptive of strength, vigor and vitality.[31] Ojas is circulated all over the body with Rasa and Rakta dhatus through specialized channels of circulation called Ojovaha sira. Abhigata (traumatic injury), Dhyana (excessive thinking), Kshaya (malnourishment), Kopa (anger) leads to vitiation of Ojas.[32] Ojas play a definite role in the pathogenesis of diseases like Prameha, Mritbhakshanajanya pandu. ${ }^{[32,33] \quad \text { Present-day }}$ researches portray the concept of Ojas to Bala (strength) or Vyadhikshamatwa (immunity).[34] Ojas is also mentioned as a part of vitamins, albumins, internal secretions of testicles, and ovaries.[35] So, Ojas, when vitiated can result in immune-compromised conditions and several other disorders.

Vajikarana dravya administered after Sodhana therapy nourishes the Saptadhatu because of the Brimhana and Jivana property. Sodhana kriyas eliminate the Ama (toxic materials) from Srotas (body channels), balances Dosha and Agni. When the Dosha and Agni are functioning in the right way, Dhatus get nourished leading to the formation of Ojas in its pure way. This can bring immunity and the absence of infirmities.

\section{Mode of Action}

The probable mode of action of Vajikarana can be described based on the combined effect of Poorvakarma and Vajikarana dravyas on dhatu. Sodhana makes the body and Srotas free from the accumulated toxic material called Ama. In a person where homeostasis of Tridosha is disturbed, anabolism and catabolism will be compromised and it leads to inadequate functioning of excretory organs. Accumulation of morbid matters leads to defective nutrition and immunity. Sodhana plays a significant role in expelling the morbid matters out from the body and thus the free radicals are expelled eventually leading the system to normalcy. Jataragni (digestive fire) is increased and Doshas are balanced.[36] Vajikarana dravyas given after the Sodhana with Jeevaniya, Brimhana Guna nourishes the body tissues. The nourished Dhatu presents with functions like Preenana, Jeevana etc. Ojas, the quintessential part of Sapta dhatu will reach its optimal stage and prevents the recurrence of diseases and promotes health. Vajikarana dravyas are administered only after Sodhana procedures.[37] Ritusodhana is a preventive Panchakarma modality meant to eliminate the seasonally aggravated Doshas. Vamana, Virechana and Basti are mentioned during Vasantha, Sharad and Varsha ritu respectively.[38] Vajikarana dravya provided after Ritu sodhana therapies will be more effective. 
The mind also plays an important role in getting the benefits of the Vajikarana on the entire body. During the entire process of this therapy, the mind should be kept free from stress and worries. Once when the body channels are free from toxic accumulation, the mind is also cleared and the Brimhana and Jeevaniya properties of medicines will reflect on maintaining health. The drugs used for Vajikarana are found to be having a neuroendocrinological effects, psycho-neuro- immunological effects, anti-inflammatory and anti-oxidant properties.

Intake of Madhura snigdha jeevaneeya dravya

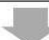

Dhathu Pushti through samanya vridhi niyama

Chief functions of dhathu like nourishment enlivening etc. are expressed in the body

Proper metabolized dhathu result in the formation of good quality ojas

Optimal ojas maintains dynamic stage of health

Figure 2: mode of action of Vajikarana drugs Modern perspective of Ojas and virility

Sex Hormones and Their Impact on Different Body Systems

Androgens (testosterone) and Estrogens (estradiol) are the primary sex hormones. Both the hormones are mainly derived from progestins or pregnenolone via dehydroepiandrosterone, androstenedione, and androstenediol, which are formed from cholesterol upon stimulation by Adrenocorticotropic Hormone (ACTH). Sex hormones differ in their site of origin and quantity. ${ }^{[39]}$ The activity of steroid hormones is mediated through receptors on extracellular proteins.

\section{Effects on Musculoskeletal System}

Sex steroids influence the maintenance and growth of muscles. A decline in Androgen, Progesterone and Estrogen by aging leads to loss of muscle mass and Sarcopenia. ${ }^{[40]}$ Estrogen interacts with Calcitonin, Parathyroid hormone, vitamin D and interleukin. Estrogen stimulates the growth and division of skin cells, connective tissue and mucosal membrane.

\section{Effects on Cardiovascular System}

Estrogen exerts a beneficial effect on the cardiovascular system like prevention of vasoconstriction, platelet aggregation and production of Prostacyclin. ${ }^{[40]}$ Estrogen plays a protective effect in women of the reproductive period. ${ }^{[41]}$ Low incidence of cardiovascular diseases like stroke, atherosclerosis and hypertension could be due to the protective effect of estrogen on endothelial function.

\section{Effect on Central Nervous System}

Sex hormones influence mood, cognitive function, pain and opioid sensitivity through receptors present in the presynaptic terminals, mitochondria and postsynaptic dendrites. ${ }^{[42]}$

\section{Effect on Immune System}

The immune, endocrine and central nervous systems are integrated through a network of hormones, cytokines and neurotransmitters. As a result of this interaction, sex hormones supplement their effects on the development and function of the immune system. ${ }^{[43]}$ The number of immune cells is increased by the influence of sex steroids. Estrogen and progesterone are the key regulators of the immune system. Sex hormones also create sexual dimorphism where females exhibit a greater immune response.[44]

The practice of Vajikarana alters the deformities of the reproductive system which in turn balances other body functions. ${ }^{[45]}$ The use of Vajikarana drugs with anti-oxidant, anti-inflammatory, immunomodulatory properties employ their effect on diverse body systems and thus maintains the general health of individuals.

\section{Women Perspectives}

Women were considered as a Vajikarana dravya (aphrodisiac). In Kashyapa Samhita few formulations were described for the health of the reproductive system of women. They should be encouraged to practice the Sodhana procedures and use of Vajikarana formulations in their reproductive age to ensure the health of off springs. Studies conducted on drugs like Shatavari and Satapushpa showed the presence of phytoestrogens with a beneficial effect on hyper and hypoestrogenic states. Consumption of phytoestrogen rich food in the daily diet (in the form of Satavari panaka or Lashuna ksheerapaka) will boon female health especially in post-menopausal complications and prevents the adverse effects arising from hormone replacement therapy. As advancements in science, it is necessary to explore these areas of research and formulate drugs that maintain and enhance the reproductive health of women.

\section{CONCLUSION}

To achieve all the objects of human pursuitDharma (moral values), Artha (economic values), Kama (psychological values), Moksha (liberation) health is considered as the primary tool. Ayurveda aims to preserve and promote health along with the prevention and cure of ailments. Vajikarana or Vrishya chikitsa is one of the eight specialties of Ayurveda. The specific branch of Ayurveda mainly focuses on 
aphrodisiacs, virility and improving the health of progeny. The proper use of the Vajikarana formulations imparts qualities like good physique, potency, strength and complexion. The benefits of Vajikarana can be incorporated into other health conditions also. The practice of Vajikarana formulations which is administered after Sneha, Sweda and Vasti balances the Agni, Tridosha and Saptadhatu. Ojas, which is considered a vital factor, is responsible for the development and maintenance of the body, is enhanced by the practice of Vajikarana formulations. Modern research studies show that sex hormones exert their effects on other body systems. The practice of Vajikarana corrects the deformities of reproductive systems and in turn balances other body functions.

\section{REFERENCES}

1. Charaka Samhita, Chiktsa sthana, samyoga saramooleeyam vajikarana padam, 2/9-11. Available from: http://niimh.nic.in/ebooks/ ecaraka. [Last accessed on 2021 May 23]

2. Pal M. The tridosha theory. Anc Sci Life. 1991; 10(3):144-155

3. Hankey A. CAM Modalities Can Stimulate Advances in Theoretical Biology. Evid Based Complement Alternat Med. 2005 Mar; 2(1):5-12.

4. Byadgi PS. The concept of immunity in Ayurveda. J Appl Pharm Sci 2011; 01:21-4

5. Agnivesha Charaka Samhita Charaka Samhita, Chiktsa sthana, samyoga saramooleeyam vajikarana padam, 2/12. Available from: http://niimh.nic.in/ebooks/ecaraka.[Last accessed on 2021 May 23]

6. Klein JR. Dynamic Interactions between the Immune System and the Neuroendocrine System in Health and Disease. Front Endocrinol (Lausanne). 2021; 12: 655982. Published 2021 Mar 22. doi:10.3389/fendo.2021.655982

7. Singh N, Bhalla M, de Jager P, Gilca M. An overview on ashwagandha: a Rasayana (rejuvenator) of Ayurveda. Afr J Tradit Complement Altern Med. 2011; 8(5 Suppl): 208

8. Lopresti AL, Smith SJ, Malvi H, Kodgule R. An investigation into the stress-relieving and pharmacological actions of an ashwagandha (Withania somnifera) extract: A randomized, double-blind, placebo-controlled study. Medicine (Baltimore). 2019;98(37)

9. Birla H, Keswani C, Rai SN, et al. Neuroprotective effects of Withania somnifera in BPA inducedcognitive dysfunction and oxidative stress in mice. Behav Brain Funct. 2019; 15(1):9. Published 2019 May 7.

10. Gautam M, Saha S, Bani S, Kaul A, Mishra S, Patil D, Satti NK, Suri KA, Gairola S, Suresh K, Jadhav S, Qazi GN, Patwardhan B. Immunomodulatory activity of Asparagus racemosus on systemic Th1/Th2 immunity: implications for immunoadjuvant potential. J Ethnopharmacol. 2009 Jan 21; 121(2):241-7.

11. Arora D, Kumar M, Dubey SD, Sings U. Immunomodulating effects of rasayana drugs in diabetics- a clinical study. Anc Sci Life. 2002; 22(2):42-48.

12. Charaka Samhita, sutra sthana, kiyanta siraseeyam adhyayam, 17/75. Available from: http://niimh.nic. in /ebooks/ecaraka. [Last accessed on 2021 May 23].

13. Charaka Samhita, sutra sthana, kiyanta siraseeyam adhyayam, 17/117. Available from: http://niimh. nic.in/ebooks/ecaraka. [Last accessed on 2021 May 23].

14. Charaka Samhita, sutra sthana, vividhasitha peethiyam adhyayam, 28/32. Available from: http://niimh.nic.in/ebooks/ecaraka.[Last accessed on 2021 May 24].

15. Sastri Paradaka HS, Acharya B, editors. Ashtanga Hridaya of Vagbhata with the Sarvangasundara Commentary of Arunadatta, sareera sthana, garbhavakranthi sareera, 1/17. Varanasi: Chaukhamba Surbharati Prakashan; 2017. p. 102.

16. Charaka Samhita, Chiktsa sthana, samyoga saramooleeyam vajikarana padam, 2/1-4. Available from: http://niimh.nic.in/ebooks/ ecaraka. [Last accessed on 2021 May 27].

17. Sushruta Samhitha, chiktsa Sthana, Vajikarana Adhyaya, 26. Available from: http://niimh.nic.in/ ebooks/esushruta. [Last accessed on 2021 May 27]

18. Kashyapa Samhita, Khila Sthana, 10. Available from: http:// niimh.nic.in/ebooks/echarak. [Last accessed on 2021 May 28].

19. Charaka Samhita, chikitsa sthana, Prameha chikitsa, 6/8. Available from: http://niimh.nic.in /ebooks/ecaraka. [Last accessed on 2021 May 27].

20. Charaka Samhita, chikitsa sthana, Vatavyadhi chikitsa, 28/213. Available from: http://niimh. nic.in/ebooks/ecaraka. [Last accessed on 2021 May 27].

21. Agrawal AK, Yadav CR, Meena MS. Physiological aspects of Agni. Ayu. 2010; 31(3):395-398.

22. Sastri Paradaka HS, Acharya B, editors. Ashtanga Hridaya of Vagbhata with the Sarvangasundara Commentary of Arunadatta, utharasthana, vajikarana adhyaya, 40/1-3. Varanasi: Chaukhamba Surbharati Prakashan; 2017. p. 770.

23. Sastri Paradaka HS, Acharya B, editors. Ashtanga Hridaya of Vagbhata with the Sarvangasundara Commentary of Arunadatta, sutra sthana, roganulpadaneeya adhyaya, 4/34, Varanasi: Chaukhamba Surbharati Prakashan; 2017. p. 87.

24. Gautam M, Saha S, Bani S, et al. Immunomodulatory activity of Asparagus racemosus on systemic Th1/Th2 immunity: implications for immuno 
adjuvant potential. Journal of Ethnopharmacology. 2009 Jan; 121(2):241-247.

25. Ghanekar BG, editor. Commentary on Sushruta Samhita, Sootrasthana; Doshadhatumala Kshayavriddhi Vidnyan. Ch. 15, Reprint. New Delhi: Meherchand Laxmandas Publications; 2008. p. 95

26. Anjali sharma, Sujata Kadam. Review article on uses of Shatapushpa in various forms in Stri Roga and Prasuti tantra. World Journal of Pharmaceutical Research. 2020 Volume 9, Issue 11, 480-489. DOI: 10.20959/wjpr202011-18701

27. Gujarathi, Jasmine \& Gujarathi, Ritesh. Maintaining Women Health Through Ayurveda. Inetrnational Ayurvedic Medical Journal. 2019; 7 (11): 2077-80

28. Athira KS, Tripathy TB, Sukumar BS. Ayurvedic food supplements for sexual health: a review article. Int J Health Sci Res. 2019; 9(5):347-355

29. Hema Sharma Datta, S.K. Mitra, Rangesh Paramesh, Bhushan Patwardhan, "Theories and Management of Aging: Modern and Ayurveda Perspectives", Evidence-Based Complementary and Alternative Medicine, vol. 2011, pg. 6 pages

30. Sushrut Samhita; Dr.Shastri Ambicadutt; Sutrasathana. 35/34-36, Varanasi: Chaukhamba Sanskrit Sansthan; 2002. p. 134-35.

31. Rammohan V. Rao, Ayurveda and the science of aging, Journal of Ayurveda and Integrative Medicine. Volume 9, Issue 3; 2018.Pg. 225-232

32. Charaka Samhita, Chiktsa sthana, rasayana padam, 1/1-4. Available from: http://niimh.nic.in/ebooks /ecaraka. [Last accessed on 2021 May 23].

33. Murthy S. K. R. Bhavaprakasa of Bhavamisra. I. Varanasi, India: Chowkhambha Krishnadas Academy; 2004. 5/13

34. Sastri Paradaka HS, Acharya B, editors. Ashtanga Hridaya of Vagbhata with the Sarvangasundara Commentary of Arunadatta, sutra sthana, ayushkameeya adhyaya, 1/20. Varanasi: Chaukhamba Surbharati Prakashan; 2017. p. 30.

35. Charaka Samhita, chikitsa sthana, Prameha chikitsa, 6/8. Available from: http://niimh.nic.in/ ebooks/ecaraka. [Last accessed on 2021 May 27].

36. Katzenschlager R, Evans A, Manson A, et al. Mucuna pruriens in Parkinson's disease: a double blind clinical and pharmacological study. J Neurol Neurosurg Psychiatry. 2004; 75(12):1672-1677.

37. Dharmarajan, Satheesh \& Muthu, A. \& Arul Gnana Dhas, Anton Smith \& Manavalan, R. In vitro antioxidant activity of various extracts of whole plant of Mucuna pruriens (Linn). International Journal of Pharm Tech Research. 2010; 2. 20632070.

38. Deore, Sharada \& Khadabadi, Somashekhar. Antiinflammatory and antioxidant activity of Chlorophytum borivilianum root extracts. Asian Journal of Chemistry. 2008; 20. 983-986.

39. Sarrel PM. Ovarian hormones and the circulation. Maturitas 2009; 12:122:287-292.

40. Yong Jin Kim, Amin Tamadon, Hyun Tae Park, Hoon Kim, Seung-Yup $\mathrm{Ku}$, The role of sex steroid hormones in the pathophysiology and treatment of sarcopenia, Osteoporosis and Sarcopenia, Volume 2, Issue 3, 2016, Pages 140-155, https://doi.org/ 10.1016/j.afos.2016.06.002.

41. Dos Santos, Roger Lyrio, da Silva, Fabrício Bragança, Ribeiro, Rogério Faustino and Stefanon, Ivanita. "Sex hormones in the cardiovascular system" Hormone Molecular Biology and Clinical Investigation, vol. 18, no. 2, 2014, pp. 89-103. https://doi.org/10.1515/hmbci-2013-0048

42. McEwen BS, Milner TA. Understanding the broad influence of sex hormones and sex differences in the brain. J Neurosci Res. 2017 Jan 2;95(1-2):2439. doi: 10.1002/jnr.23809.

43. Nassrin Malik Aubead. Role of Sex Hormones in Human Body. 2021; 3-4. DOI: 10.5772/ intechopen. 95778

44. Bhatia A, Sekhon HK, Kaur G. Sex hormones and immune dimorphism. Scientific World Journal. 2014; 2014: 159150. doi: 10.1155/2014/159150. Epub 2014 Nov 17.

45. Kamla Kant Shukla, Abbas Ali Mahdi, Mohammad Kaleem Ahmad, Shyam Pyari Jaiswar, Satya Narain Shankwar, Sarvada Chandra Tiwari, Mucuna pruriens Reduces Stress and Improves the Quality of Semen in Infertile Men, Evidence-Based Complementary and Alternative Medicine. 2010; vol.7,PP.8,https://doi.org/10.1093/ecam/ nem171

\section{Cite this article as:}

Anusree Dileep, Sreelekshmi.S, Vandana Rani.M, Delvin.T.Robin, Meera.S. Utility of Vajikarana in General Health- A Review. International Journal of Ayurveda and Pharma Research. 2021;9(8):57-63.

https://doi.org/10.47070/ijapr.v9i8.1978

Source of support: Nil, Conflict of interest: None Declared
*Address for correspondence

\section{Dr. Anusree Dileep}

Associate Professor,

PG Department of Swasthavritta,

(Social and Preventive Medicine),

Amrita School of Ayurveda,

Amritapuri, Amrita Vishwa

Vidyapeetham, India.

Email: dranusree15@gmail.com

Disclaimer: IJAPR is solely owned by Mahadev Publications - dedicated to publish quality research, while every effort has been taken to verify the accuracy of the content published in our Journal. IJAPR cannot accept any responsibility or liability for the articles content which are published. The views expressed in articles by our contributing authors are not necessarily those of IJAPR editor or editorial board members. 